\title{
Effects of Aging Treatment on Laser-Welded Mg-Rare Earth Alloy NZ30K
}

\author{
Jun Dai, ${ }^{1,2}$ Li Yang, ${ }^{1}$ Lili Li, ${ }^{3}$ Guolin Guo, ${ }^{1}$ and Lanzhong Guo \\ ${ }^{1}$ School of Mechanical Engineering, Changshu Institute of Technology, Changshu 215500, China \\ ${ }^{2}$ Shanghai Key Laboratory of Materials Laser Processing and Modification, Shanghai 200240, China \\ ${ }^{3}$ China Gridcom Company, LTD, Beijing 100070, China
}

Correspondence should be addressed to Jun Dai; jdaijs@163.com

Received 30 May 2013; Accepted 22 August 2013

Academic Editor: Aiguo Xu

Copyright (C) 2013 Jun Dai et al. This is an open access article distributed under the Creative Commons Attribution License, which permits unrestricted use, distribution, and reproduction in any medium, provided the original work is properly cited.

\begin{abstract}
Magnesium-rare earth alloys have received extensive attention due to their attractive mechanical properties resulting from high density of precipitation. The precipitation sequence in laser-welded $\mathrm{Mg}-3 \mathrm{Nd}-0.2 \mathrm{Zn}-0.4 \mathrm{Zr}(\mathrm{NZ} 30 \mathrm{~K})$ alloy during aging treatment at $200^{\circ} \mathrm{C}$ and $225^{\circ} \mathrm{C}$ has been investigated using transmission electron microscopy (TEM). The results indicate that the tensile strength of laser-welded NZ30K can be improved significantly after aging treatment at $200^{\circ} \mathrm{C}$ for $8 \mathrm{~h}$. It is found that the precipitation in laser-welded NZ30K alloy follows the sequence of supersaturated solid solution $\rightarrow \beta^{\prime \prime}\left(\mathrm{DO}_{19}\right) \rightarrow \beta^{\prime}(\mathrm{fcc})$.
\end{abstract}

\section{Introduction}

Magnesium alloys have many advantages such as high strength/weight ratios and energy saving, which are considered to be the most developing potential materials in the 21st century $[1,2]$. Different alloy compositions have been proposed to overcome the low corrosion resistance and the problems of high temperature applications of magnesium alloys. Because of good heat resistance and significant strengthening effect, many new magnesium alloys with addition of rare earth elements have been developed and studied [3-8]. NZ30K is alloyed by the rare earth element neodymium (Nd), which has been used for mechanical parts such as components in transportation system and hub of car wheels [9-12].

Although the alloy elements can improve the performance of magnesium alloy, the addition of elements alone is insufficient to meet some requirements in the engineering application. It is known that proper heat treatment can improve the properties of magnesium alloy obviously. Up to now, there are a lot of extensive researches investigating the precipitation sequences of magnesium-rare earth alloys [13-15]. It is reported that the precipitation sequence of magnesium alloy varies with different alloy elements. The precipitation sequence of binary $\mathrm{Mg}-\mathrm{Y}$ alloys was supersaturated solid solution (S.S.S.S.) $\rightarrow \beta^{\prime \prime}(\mathrm{cbco}) \rightarrow \beta^{\prime}(\mathrm{cbco}) \rightarrow$ $\beta\left(\mathrm{Mg}_{24} \mathrm{Y}_{5}, \mathrm{bcc}\right)$ [16], while that of binary $\mathrm{Mg}-\mathrm{Gd}$ alloys was $($ S.S.S.S. $) \rightarrow \beta^{\prime \prime}\left(\mathrm{DO}_{19}\right) \rightarrow \beta^{\prime}(\mathrm{cbco}) \rightarrow \beta\left(\mathrm{Mg}_{5} \mathrm{Gd}, \mathrm{fcc}\right)$ [17]. The precipitation sequence of $\mathrm{Mg}-\mathrm{Nd}$ alloys was (S.S.S.S.) $\rightarrow$ $\beta^{\prime \prime}\left(\mathrm{DO}_{19}\right) \rightarrow \beta^{\prime}(\mathrm{fcc}) \rightarrow \beta(\mathrm{bcc})[10]$. However, there was little report about the precipitation sequence in the laserwelded $\mathrm{Mg}-\mathrm{Nd}-\mathrm{Zn}-\mathrm{Zr}$ alloys.

In the present paper, a detailed examination of the precipitation sequence in laser-welded NZ30K during aging treatment is investigated, and the effects of different shape of precipitates on tensile strength are discussed.

\section{Experimental Procedure}

Test plates were the hot-rolled Mg-rare earth alloy NZ30K, which is alloyed by the rare earth element $\mathrm{Nd}$, the element Zinc $(\mathrm{Zn})$, and Zirconium (Zr). The chemical compositions of the alloy are listed in Table 1 . The dimension of test plates was $150 \mathrm{~mm} \times 75 \mathrm{~mm} \times 10 \mathrm{~mm}$.

$\mathrm{A} \mathrm{CO}_{2}$ laser source (TRUMPF TLF15000T) was used, and the experimental laser power was $8 \mathrm{~kW}$. The diameter of the laser beam focus is $0.8 \mathrm{~mm}$. The pure helium with the flow 


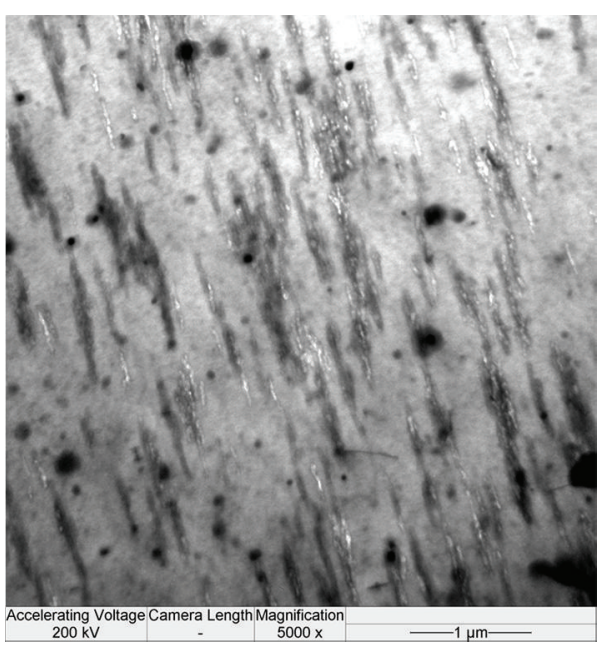

(a)

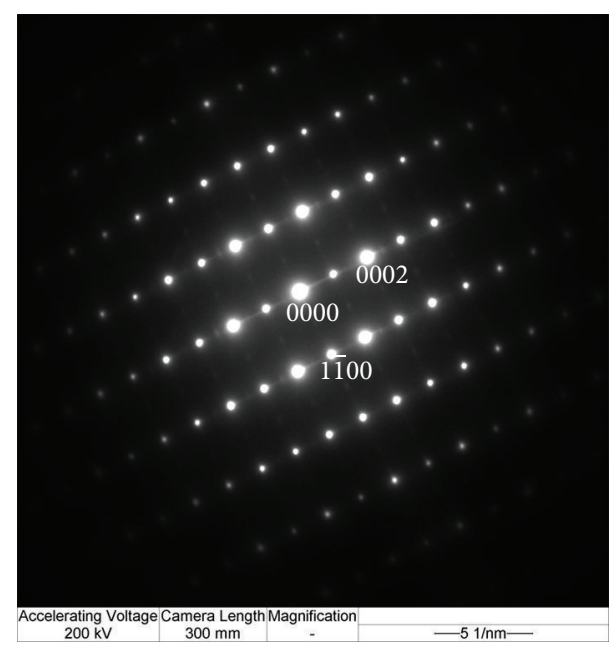

(b)

FIGURE 1: TEM image and electron diffraction pattern aged at $200^{\circ} \mathrm{C}$ for $8 \mathrm{~h}$ along $[11 \overline{2} 0]_{\alpha}$ zone axis: (a) TEM image; (b) electron diffraction pattern.

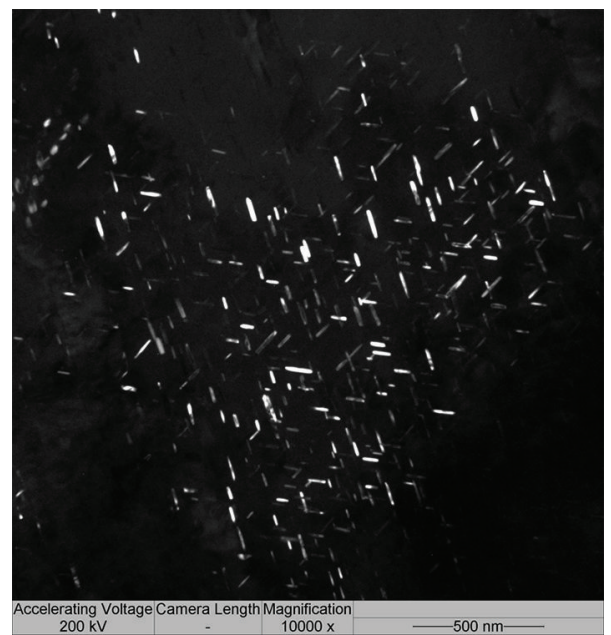

FIGURE 2: Dark field TEM image of precipitates aged at $200^{\circ} \mathrm{C}$ for $8 \mathrm{~h}$.

TABLE 1: Chemical compositions of the NZ30K (weight percent, \%).

\begin{tabular}{lcccccc}
\hline Compositions & $\mathrm{Nd}$ & $\mathrm{Zn}$ & $\mathrm{Zr}$ & $\mathrm{Fe}$ & $\mathrm{Ni}$ & $\mathrm{Mg}$ \\
Content & 3.001 & 0.2696 & 0.3752 & $<0.002$ & $<0.002$ & Balance \\
\hline
\end{tabular}

rate of $25 \mathrm{~L} / \mathrm{min}$ was used as front-side protection, and the reverse side was protected by pure Argon gas with $20 \mathrm{~L} / \mathrm{min}$.

The surface of the plates was cleaned by wire brush and then wiped by acetone before butt welding. The welded joints were solution-treated at $540^{\circ} \mathrm{C}$ for $6 \mathrm{~h}$ and quenched into hot water at above $70^{\circ} \mathrm{C}$. After the solution treatment, the joints were aging-treated at $200^{\circ} \mathrm{C}$ and $225^{\circ} \mathrm{C}$ for different hours. The parameters of heat treatments are listed in Table 2. Discs $3 \mathrm{~mm}$ in diameter were punched from fusion zone of welding joints, ground to a thickness of $0.1 \mathrm{~mm}$, and twin-jet electropolished in a solution of $95 \mathrm{~mL}$ Alcohol and
$5 \mathrm{~mL}$ Perchloric acid, at $-40^{\circ} \mathrm{C}$ and $0.05 \mathrm{~A}$. Microstructural examination was performed in a JEM-2100F TEM operating at $200 \mathrm{kV}$. As precipitation occurs in the magnesium prismatic planes, the zone axes of interest were [0001]. The tensile properties were tested by a Zwick Z020 E-stretching machine with the tensile rate $1 \mathrm{~mm} / \mathrm{min}$ at room temperature. Experiment was repeated three times for each sample.

\section{Results}

3.1. The Prismatic Precipitation. Figure 1 displays TEM results obtained on the sample aged at $200^{\circ} \mathrm{C}$ for $8 \mathrm{~h}$. It can be seen from Figure 1(b) that the precipitates can be identified as the structure hcp. According to the researches about the precipitates of $\mathrm{Mg}-\mathrm{Nd}$ alloy [10], the precipitates are probably mainly $\beta^{\prime \prime}$ phase with $\mathrm{DO}_{19}$ structure. Figure 2 shows the dark field image of precipitates. It can be seen that the 


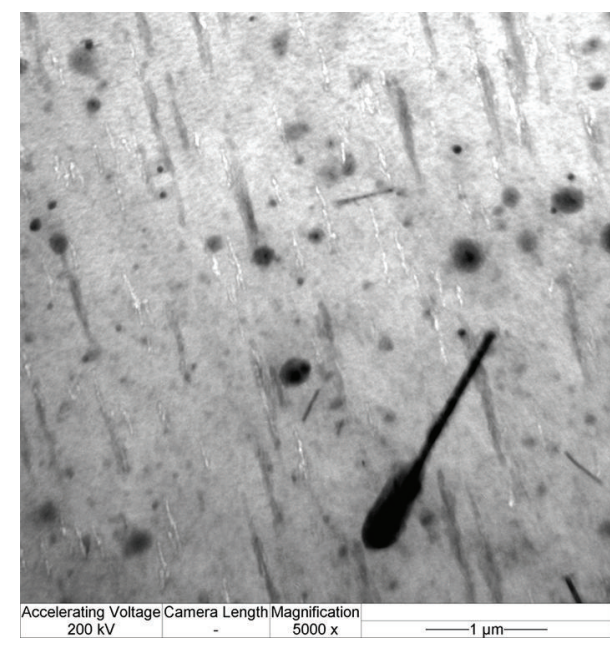

(a)

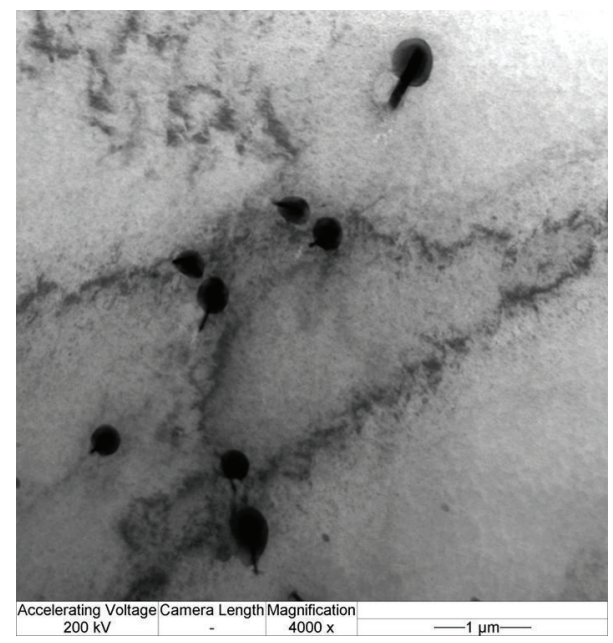

(b)

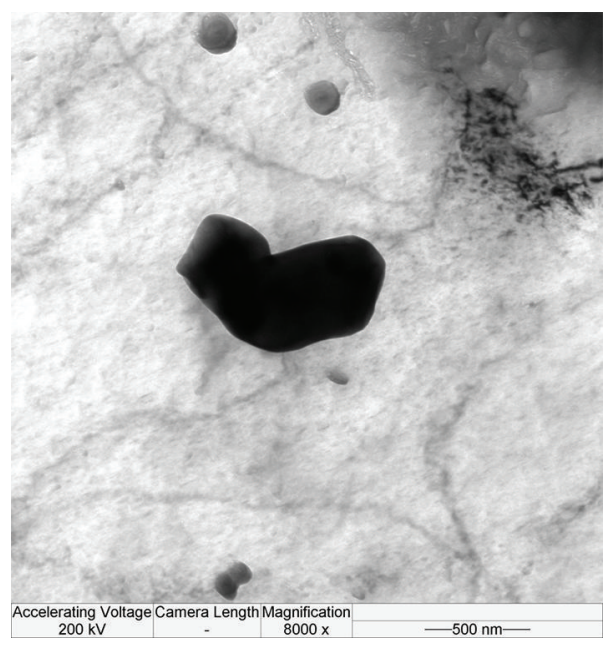

(c)

FIgURE 3: TEM morphology of the precipitates aged at $200^{\circ} \mathrm{C}$ for $8 \mathrm{~h}$ : (a) rod shape, (b) tadpole shape, (c) flake shape.

TABle 2: Parameters of heat treatments.

\begin{tabular}{ll}
\hline Sample & Parameters of heat treatments \\
\hline 1 & Laser-welded joint with no heat treatment \\
2 & $540^{\circ} \mathrm{C} \times 6 \mathrm{~h}$ solution treatment $+200^{\circ} \mathrm{C} \times 2 \mathrm{~h}$ aging \\
& treatment \\
& $540^{\circ} \mathrm{C} \times 6 \mathrm{~h}$ solution treatment $+200^{\circ} \mathrm{C} \times 8 \mathrm{~h}$ aging \\
3 & treatment \\
& $540^{\circ} \mathrm{C} \times 6 \mathrm{~h}$ solution treatment $+200^{\circ} \mathrm{C} \times 64 \mathrm{~h}$ aging \\
4 & treatment \\
& $540^{\circ} \mathrm{C} \times 6 \mathrm{~h}$ solution treatment $+225^{\circ} \mathrm{C} \times 8 \mathrm{~h}$ aging \\
5 & treatment \\
& $540^{\circ} \mathrm{C} \times 6 \mathrm{~h}$ solution treatment $+225^{\circ} \mathrm{C} \times 64 \mathrm{~h}$ aging \\
6 & treatment \\
\hline
\end{tabular}

prismatic precipitates disperse in the matrix with the contact angle of 120 degree.

Figure 3 shows the three typical morphologies of the precipitates. The precipitates exhibit rod shape, tadpole shape and flake shape in different regions as shown in Figures 3(a), 3 (b), and 3(c), respectively. After the sample aged at $200^{\circ} \mathrm{C}$ for $8 \mathrm{~h}$, the shape of precipitates is complex.

3.2. The Precipitation during Aging Treatment at $200^{\circ} \mathrm{C}$. The precipitates of sample aged at $200^{\circ} \mathrm{C}$ for $2 \mathrm{~h}$ are shown in Figure 4 . It can be seen that the precipitates exhibit both rod shape and flake shape. From Figures 4(c) and 4(e), the precipitates are almost flake shaped. The precipitates are also mainly $\beta^{\prime \prime}$ phase after aging treatment at $200^{\circ} \mathrm{C}$ for $2 \mathrm{~h}$.

Figure 5 depicts the microstructures and the electron diffraction pattern of precipitates along $[11 \overline{2} 0]_{\alpha}$ zone axis of sample aged at $200^{\circ} \mathrm{C}$ for $64 \mathrm{~h}$. As can be seen from Figure 5(a), there are flake shape precipitates. The electron diffraction pattern is the same as that of sample aged at $200^{\circ} \mathrm{C}$ for $2 \mathrm{~h}$ disclosing $\beta^{\prime \prime}$ phase.

3.3. The Precipitation during Aging Treatment at $225^{\circ} \mathrm{C}$. The precipitates of sample aged at $225^{\circ} \mathrm{C}$ for $8 \mathrm{~h}$ are shown in 


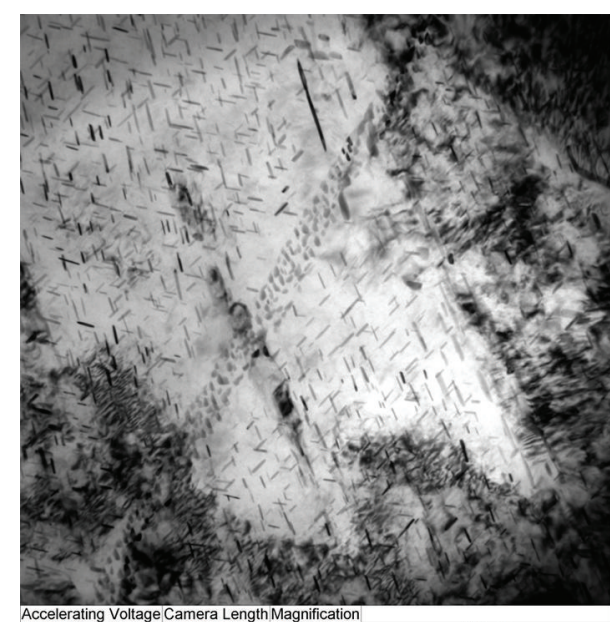

Accelerating Voltage Camera Length Magnification
$200 \mathrm{kV}$
$8000 \mathrm{x}$

(a)

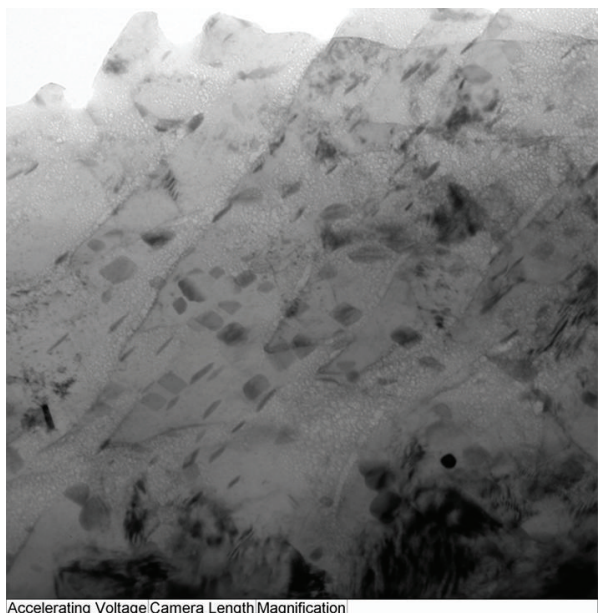

Accelerating Voltage Camera Length Magnification
$200 \mathrm{kV}$
$12000 \mathrm{x}$

(c)

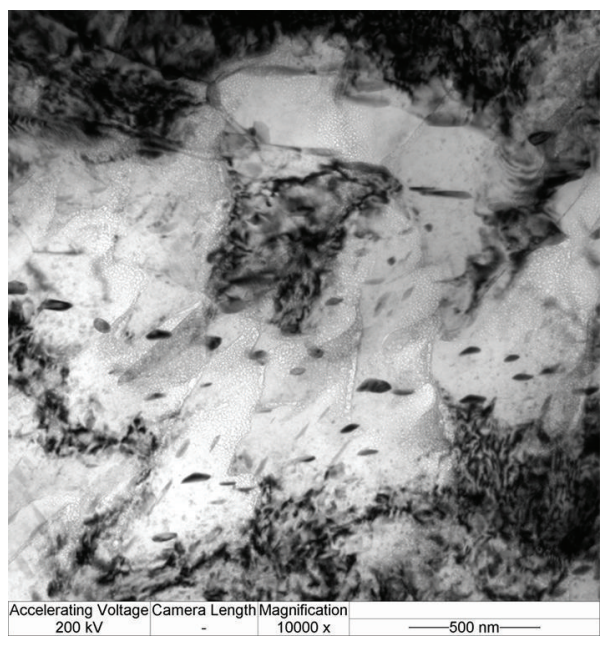

(e)

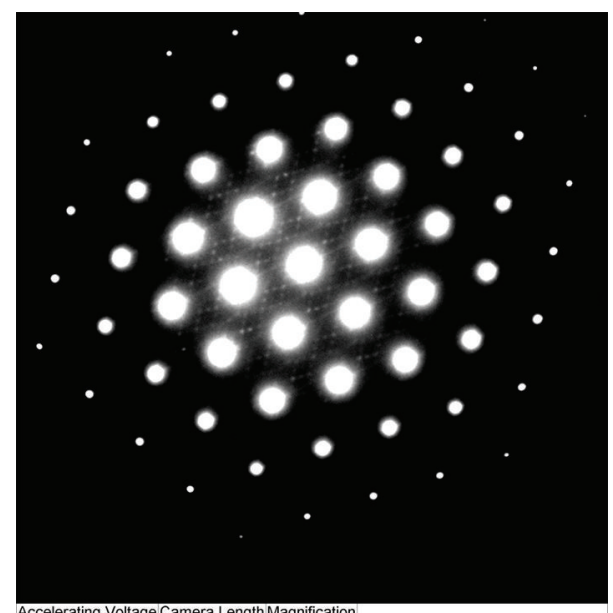

Accelerating Voltage Camera Length Magnification
$200 \mathrm{kV}$
$300 \mathrm{~mm}$

(b)

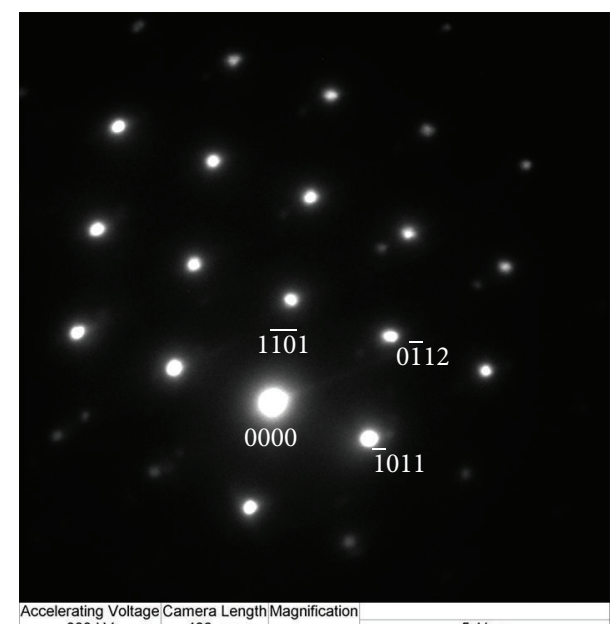

(d)

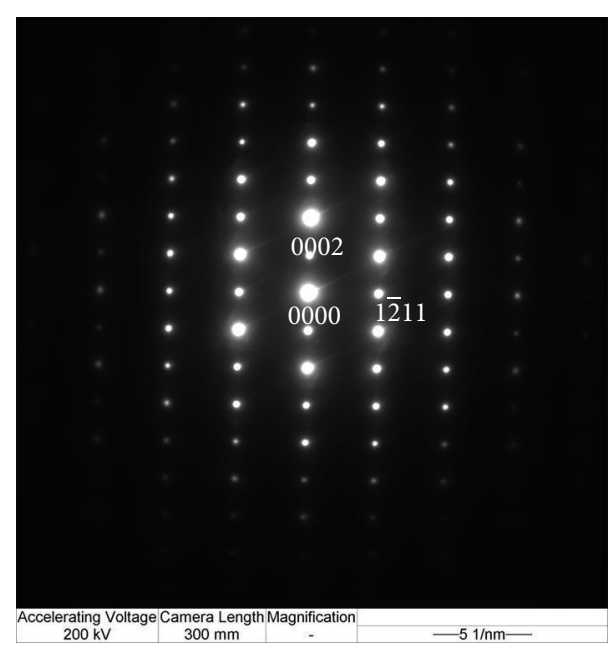

(f)

FIGURE 4: TEM image and electron diffraction pattern aged at $200^{\circ} \mathrm{C}$ for $2 \mathrm{~h}$ : (a) and (b) along $[0001]_{\alpha}$ zone axis; (c) and (d) along $[01 \overline{1} 1]_{\alpha}$ zone axis; (e) and (f) along $[11 \overline{2} 0]_{\alpha}$ zone axis. 


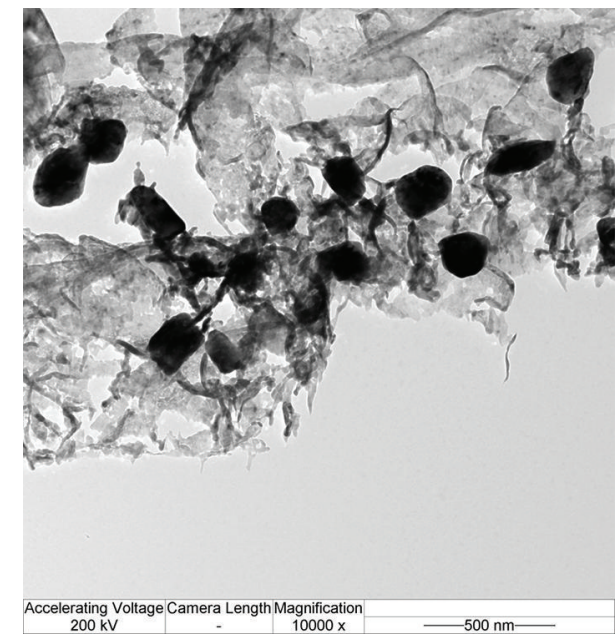

(a)

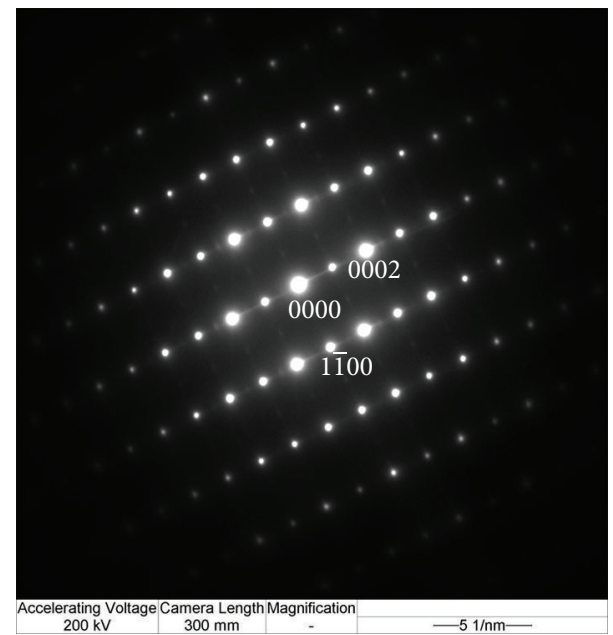

(b)

FIGURE 5: TEM image and electron diffraction pattern showing precipitates aged at $200^{\circ} \mathrm{C}$ for $64 \mathrm{~h}$ along $[11 \overline{2} 0]_{\alpha}$ zone axis: (a) TEM image; (b) electron diffraction pattern.

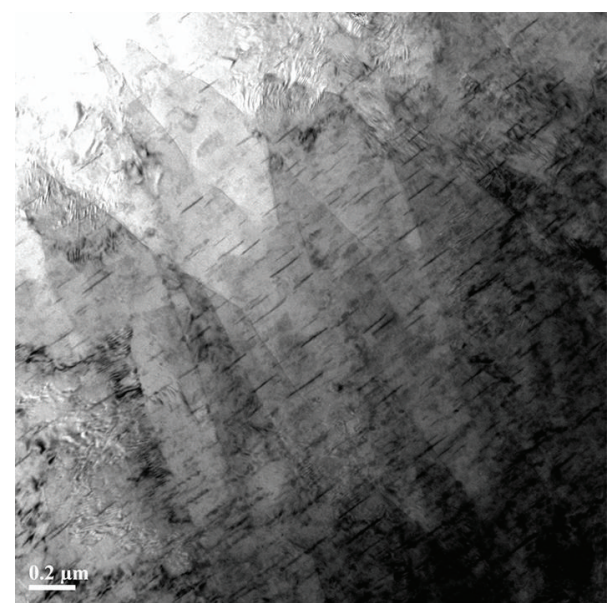

(a)

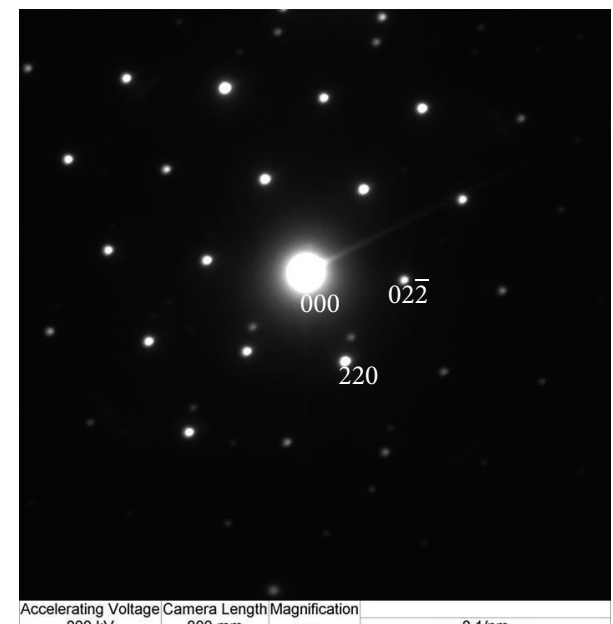

\begin{tabular}{l}
$\underset{\text { erating Voltage Camera Length Magnification }}{200 \mathrm{kV}} 800 \mathrm{~mm}$ \\
\hline
\end{tabular}

(b)

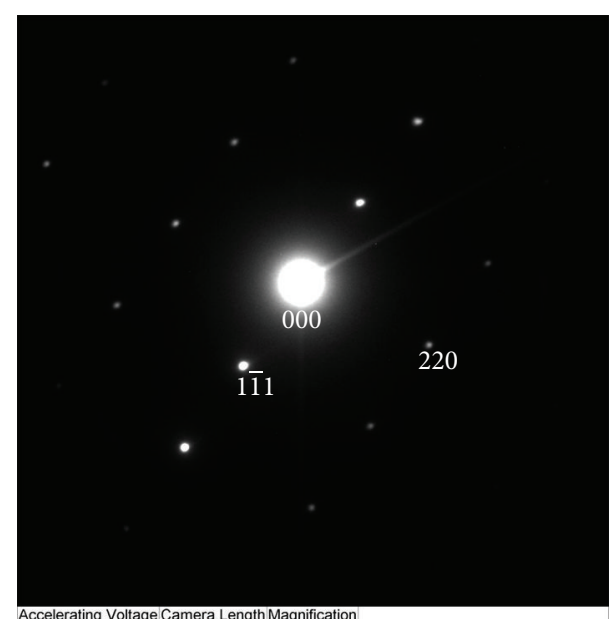

Accelerating Voltage Camera Length Magnification
$200 \mathrm{kV}$

(c)

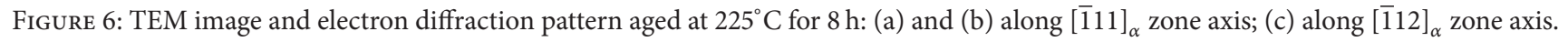




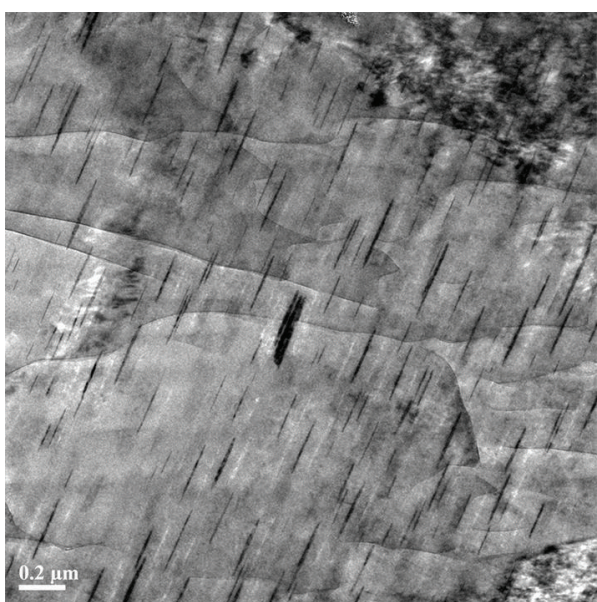

(a)

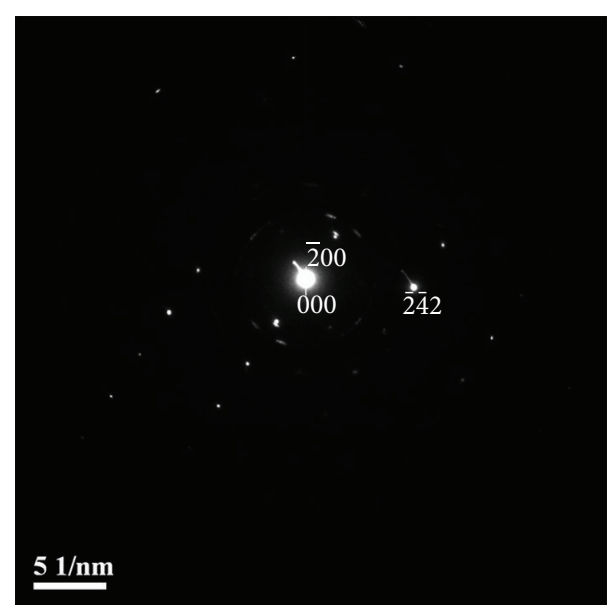

(b)

FIGURE 7: TEM image and electron diffraction pattern showing precipitates aged at $225^{\circ} \mathrm{C}$ for $64 \mathrm{~h}$ along [012 $]_{\alpha}$ zone axis: (a) TEM image; (b) electron diffraction pattern.

Figure 6. It can be seen that the precipitates are rod shaped. The electron diffraction patterns in Figures 6(b) and 6(c) indicate that the precipitates are $\beta^{\prime}$ phase with fcc atomic structure, which are different from that of precipitates after aging treatment at $200^{\circ} \mathrm{C}$.

Figure 7 depicts TEM results of samples aged at $225^{\circ} \mathrm{C}$ for $64 \mathrm{~h}$. The electron diffraction pattern is the same as that of a sample aged at $225^{\circ} \mathrm{C}$ for $8 \mathrm{~h}$ as indicated by Figure $7(\mathrm{~b})$. The precipitates are also composed of $\beta^{\prime}$ phase.

\section{Discussion}

Assuming that dislocation glide and bypass mechanisms (Orowan strengthening) only occur on (0001) basal plane, Nie amended Orowan strengthening formula according to the precipitate morphologies and habits with respect to the matrix [18]. Orowan strengthening formula is

$$
\Delta \tau=\frac{G b}{2 \pi \lambda \sqrt{1-v}} \ln \frac{d_{p}}{r_{0}},
$$

where $\Delta \tau$ is the incremental of critical shear stress component, $G$ the matrix shear modulus $\left(G=1.66 * 10^{4} \mathrm{MPa}\right), b$ the Bo's vector mode $\left(b=3.21 * 10^{-10} \mathrm{~m}\right), v$ the Poisson ratio $(v=0.35), \lambda$ the plane space between the adjacent second phase particles, $d_{p}$ the average plane diameter of the second phase particles, $f$ the volume fraction of precipitates, and $r_{0}$ the dislocation radius (here $r_{0}=b$ ). According to the formula, the different shape precipitates can affect the tensile strength.

Here the effects of different shape precipitates on tensile strength are displayed with experimental results. The tensile strength of different samples is shown in Figure 8. It can be seen that the tensile strength of sample 3 of laser-welded joints is the largest. It is because of the fact that there are lot of prismatic precipitate plates as shown in Figure 2. The size of precipitates in sample 4 is about $100 \mathrm{~nm}$. The tensile strength of sample 2 is the smallest after the aging treatment due to the basal precipitate plates after a short aging time

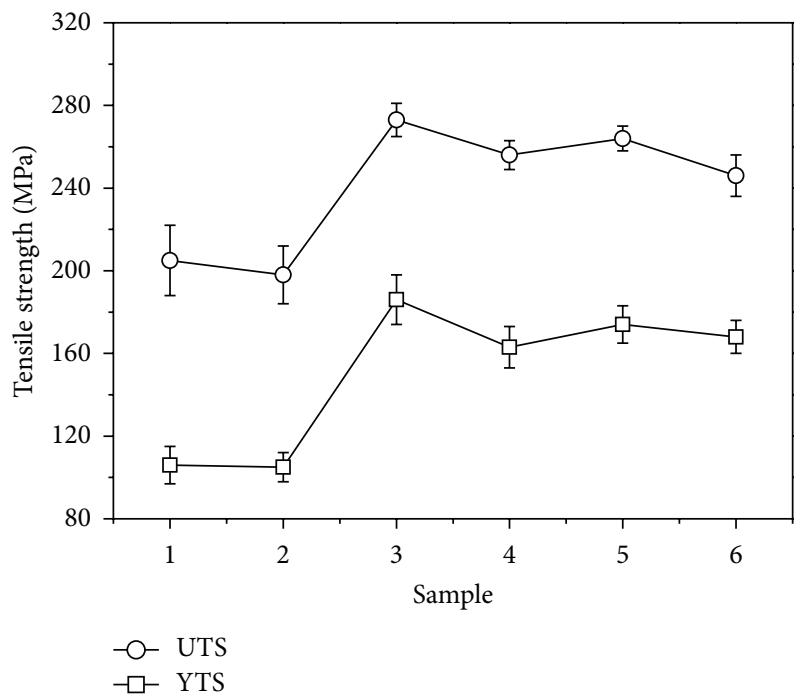

FIgURE 8: The tensile strength of samples containing different main participate morphology.

as can be seen from Figure 4(c). The size of precipitates in sample 2 is about $70 \mathrm{~nm}$. After $200^{\circ} \mathrm{C}$ aging treatment, the size of precipitates grows from $70 \mathrm{~nm}$ to $150 \mathrm{~nm}$ as the aging time increases from $2 \mathrm{~h}$ to $64 \mathrm{~h}$. When laser-welded NZ30K is aged at $225^{\circ} \mathrm{C}$, the precipitates are mainly rod shaped, which has lower strengthening effect than the prismatic precipitate plates. It is noted that the size of precipitates changes from $100 \mathrm{~nm}$ to $250 \mathrm{~nm}$ after aging treatment at $225^{\circ} \mathrm{C}$ for $8 \mathrm{~h}$ and $64 \mathrm{~h}$. The strength of sample 5 and 6 is smaller than that of sample 3 .

\section{Conclusions}

From the above results, the main conclusions can be summarized as follow. 
(1) It is found that the precipitation sequence of laserwelded NZ30K follows supersaturated solid solution $($ S.S.S.S. $) \rightarrow \beta^{\prime \prime}\left(\mathrm{DO}_{19}\right) \rightarrow \beta^{\prime}(\mathrm{fcc})$.

(2) After aging treatment at $200^{\circ} \mathrm{C}$ for $8 \mathrm{~h}$, the tensile strength of the laser-welded NZ30K can be improved significantly.

\section{Acknowledgments}

The project is supported by the Natural Science Research Project of College in Jiangsu Province (13KJB430001) and Changshu Institute of Technology (KYZ2013004Z). It was also supported by Open Fund of Shanghai Key Laboratory of Materials Laser Processing and Modification. The authors want to give thanks to Mr. J. Huang and Mr. J. Dong from Shanghai Jiao Tong University for providing the experimental materials. Special thanks are due to Mr. B. Chen and Miss M. Li for assistance in experiments.

\section{References}

[1] Z. Yang, J. P. Li, J. X. Zhang, G. W. Lorimer, and J. Robson, "Review on research and development of magnesium alloys," Acta Metallurgica Sinica, vol. 21, no. 5, pp. 313-328, 2008.

[2] N. Hort, Y. Huang, D. Fechner et al., "Magnesium alloys as implant materials-principles of property design for Mg-RE alloys," Acta Biomaterialia, vol. 6, no. 5, pp. 1714-1725, 2010.

[3] X. Zheng, J. Dong, Y. Xiang et al., "Formability, mechanical and corrosive properties of $\mathrm{Mg}-\mathrm{Nd}-\mathrm{Zn}-\mathrm{Zr}$ magnesium alloy seamless tubes," Materials and Design, vol. 31, no. 3, pp. 14171422, 2010.

[4] T. L. Chia, M. A. Easton, S. M. Zhu, M. A. Gibson, N. Birbilis, and J. F. Nie, "The effect of alloy composition on the microstructure and tensile properties of binary Mg-rare earth alloys," Intermetallics, vol. 17, no. 7, pp. 481-490, 2009.

[5] M. Hisa, J. C. Barry, and G. L. Dunlop, "New type of precipitate in Mg-rare-earth alloys," Philosophical Magazine A, vol. 82, no. 3, pp. 497-510, 2002.

[6] L. L. Rokhlin, "Regularities of the Mg sides of the Mg-RE (magnesium-rare earth metal) phase diagrams: comments on evaluations," Journal of Phase Equilibria, vol. 16, no. 6, pp. 504507, 1995.

[7] X. Zeng, Y. Wang, W. Ding, A. A. Luo, and A. K. Sachdev, "Effect of strontium on the microstructure, mechanical properties, and fracture behavior of AZ31 magnesium alloy," Metallurgical and Materials Transactions A, vol. 37, no. 4, pp. 1333-1341, 2006.

[8] F. Khomamizadeh, B. Nami, and S. Khoshkhooei, "Effect of rare-earth element additions on high-temperature mechanical properties of AZ91 magnesium alloy," Metallurgical and Materials Transactions A, vol. 36, no. 12, pp. 3489-3494, 2005.

[9] J. W. Chang, L. M. Peng, X. W. Guo et al., "Comparison of the corrosion behaviour in $5 \% \mathrm{NaCl}$ solution of $\mathrm{Mg}$ alloys NZ30K and AZ91D," Journal of Applied Electrochemistry, vol. 38, no. 2, pp. 207-214, 2008.

[10] P. H. Fu, L. M. Peng, H. Y. Jiang, J. W. Chang, and C. Q. Zhai, "Effects of heat treatments on the microstructures and mechanical properties of $\mathrm{Mg}-3 \mathrm{Nd}-0.2 \mathrm{Zn}-0.4 \mathrm{Zr}$ (wt.\%) alloy," Materials Science and Engineering A, vol. 486, no. 1-2, pp. 183192, 2008.
[11] J. W. Chang, X. W. Guo, P. H. Fu, L. M. Peng, and W. J. Ding, "Effect of heat treatment on corrosion and electrochemical behaviour of Mg-3Nd-0.2Zn-0.4Zr (wt.\%) alloy," Electrochimica Acta, vol. 52, no. 9, pp. 3160-3167, 2007.

[12] J. W. Chang, P. H. Fu, X. W. Guo, L. M. Peng, and W. J. Ding, "The effects of heat treatment and zirconium on the corrosion behaviour of Mg-3Nd-0.2Zn-0.4Zr (wt.\%) alloy," Corrosion Science, vol. 49, no. 6, pp. 2612-2627, 2007.

[13] G. Barucca, R. Ferragut, F. Fiori et al., "Formation and evolution of the hardening precipitates in a Mg-Y-Nd alloy," Acta Materialia, vol. 59, no. 10, pp. 4151-4158, 2011.

[14] G. Barucca, R. Ferragut, D. Lussana, P. Mengucci, F. Moia, and G. Riontino, "Phase transformations in QE22 Mg alloy," Acta Materialia, vol. 57, no. 15, pp. 4416-4425, 2009.

[15] J. F. Nie, X. L. Xiao, C. P. Luo, and B. C. Muddle, "Characterisation of precipitate phases in magnesium alloys using electron microdiffraction," Micron, vol. 32, no. 8, pp. 857-863, 2001.

[16] H. Karimzadeh, J. M. Worrall, R. Pilkington, and G. W. Lorimer, Proceedings Magnesium Technology, London, UK, 1st edition, 1986.

[17] B. Smola, I. Stulıková, F. von Buch, and B. L. Mordike, "Structural aspects of high performance $\mathrm{Mg}$ alloys design," Materials Science and Engineering A, vol. 324, no. 1-2, pp. 113-117, 2002.

[18] J. F. Nie, "Effects of precipitate shape and orientation on dispersion strengthening in magnesium alloys," Scripta Materialia, vol. 48, no. 8, pp. 1009-1015, 2003. 

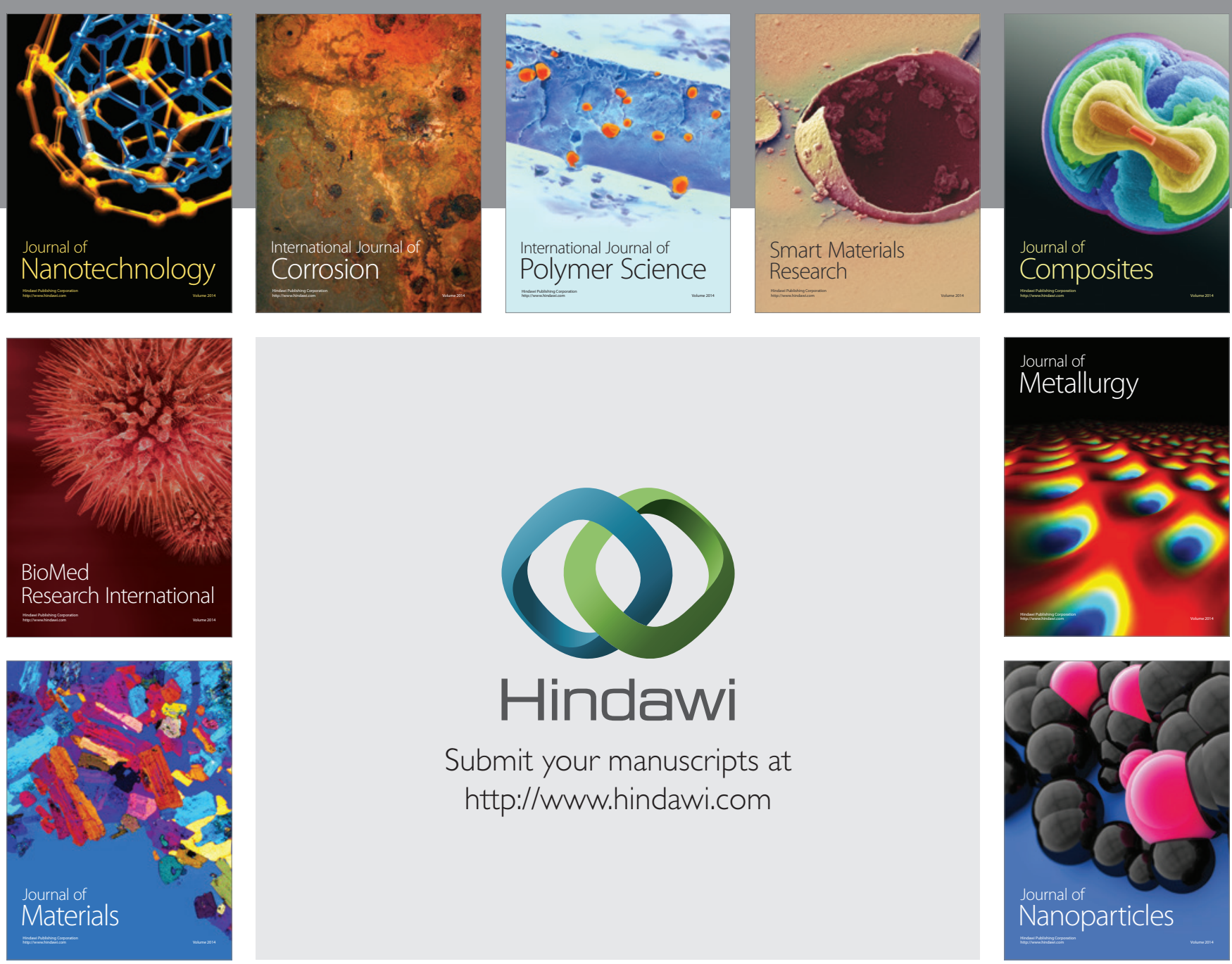

Submit your manuscripts at http://www.hindawi.com
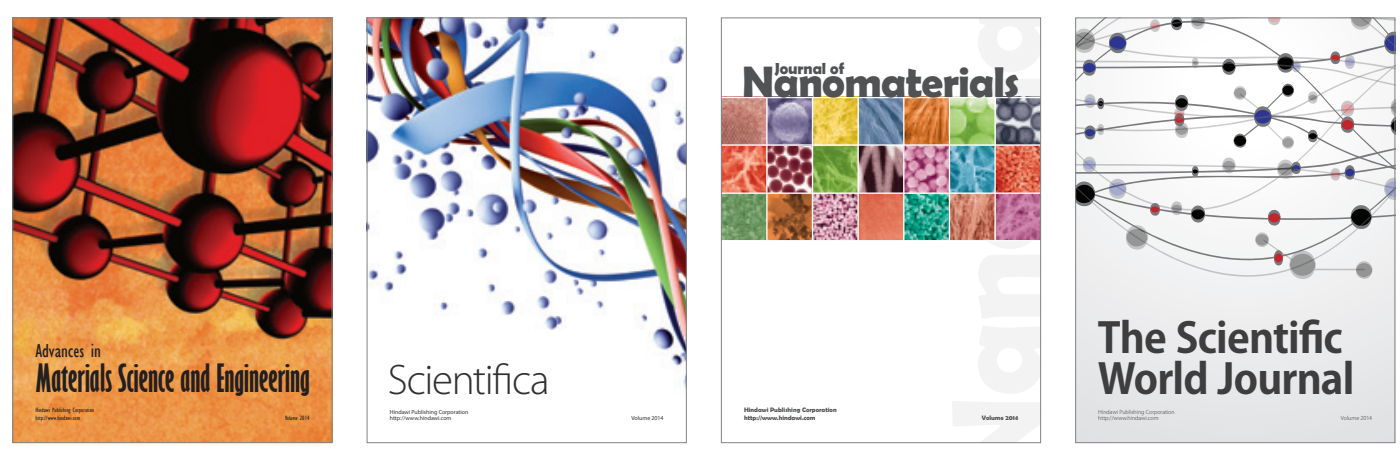

\section{The Scientific World Journal}
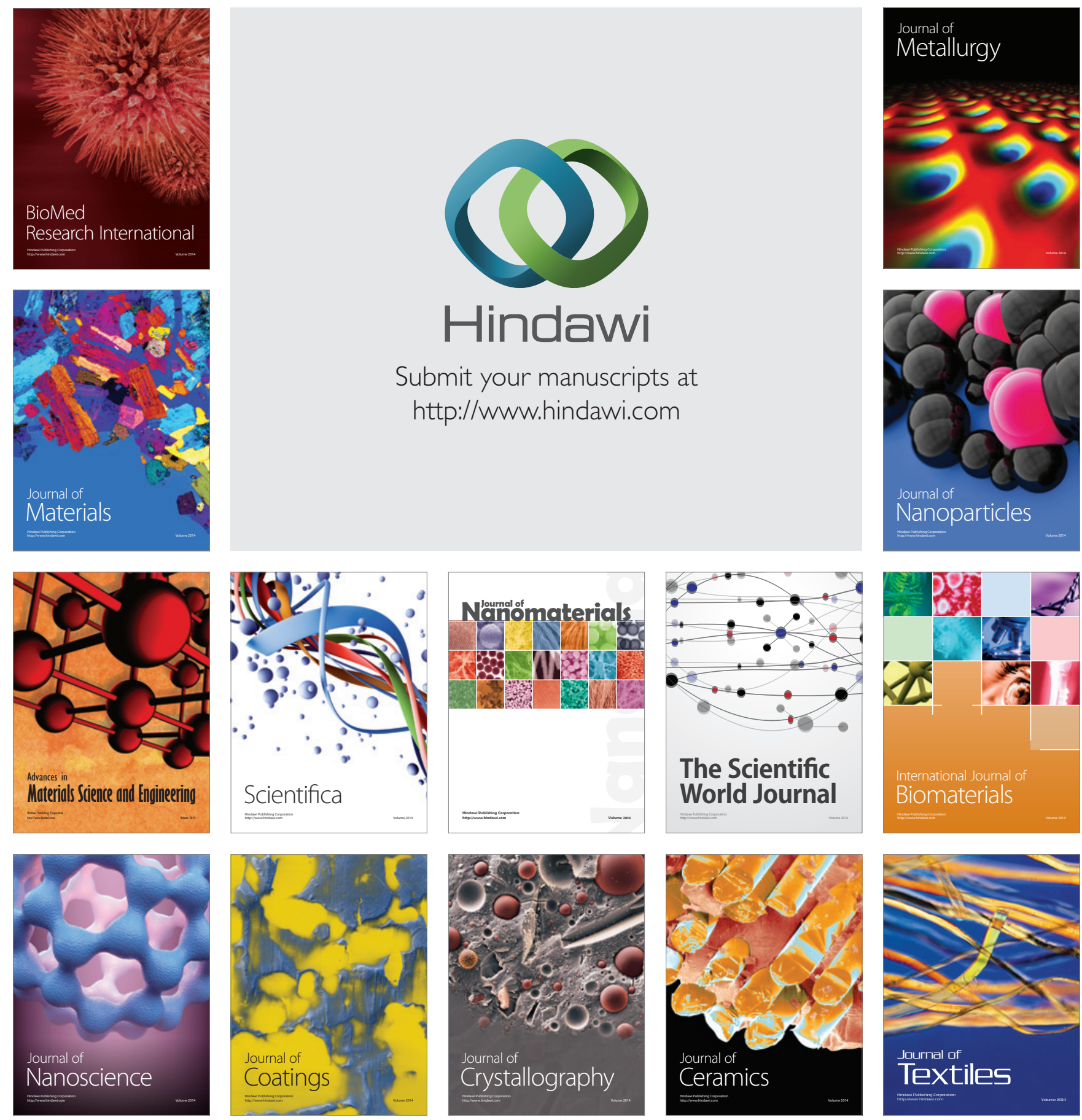